\title{
MEN SITUATION IN BYZANTINE COMMUNITY
}

\author{
Dr.N.Gnanakumaran
}

Department Of Philosophy, University Of Jaffna, Thirunelvely, Sri Lanka

\section{ABSTRACT}

Albeit Byzantine community was a general public of disparity both between the social layers and the privileges of the two genders, men in Byzantine occasions assumes a significant part. he coordinates business, takes part in the congregation as a religious recluse or church assistant, and assumes a functioning part in political issues. It additionally has equivalent rights with men to give and acquire their property. Obviously, it is as yet avoided from public workplaces with exceptional, maybe permitted, occupations of drawing in with family, religion and noble cause. Fundamental credits of the ideal men and spouse are virginity, quietness and resistance. Byzantine instruction has guaranteed rudimentary schooling for some men . The Byzantine men wedded early and was viewed as the top of the family and the defender of his youngsters particularly in the event that she was a widow and her kids were still extremely youthful.

KEYWORDS:- Men, family, religion, instruction, boy, separate, , slave, Augusta, community

\section{INTRODUCTION}

In the course of time, Byzantium changed its structure, as the boundaries developed, the political, regulatory, monetary and military designs were expanded and its character continually acclimated to the new conditions. Additionally, the various people groups, who made the populace out of the Empire, carried with them separate traditions and customs, which the Roman organization had not bound together. These changes, without a doubt, influenced the situation of the men in the public eye. All things considered, the social legacy of Rome varied from that of the men of the East or of Egypt, with the outcome, for the initial not many hundreds of years, that the picture of the male presence seemed distinctive in various places. Then, the state association, joined with the Greek instruction, which was the social foundation of Byzantium, and the Christianity that every one of its residents embraced, added to the unification of conditions and conditions, yet didn't completely wipe out the distinctions. Along these lines, the part of men in Byzantium doesn't present a solitary picture in space and time.

\section{Methods}

Not with standing, the issue of taking force from the men isn't especially dumbfounding. As a rule, the Byzantines have treated the force of men with some restraint, yet they don't relinquish the 
CURRENT RESEARCH JOURNAL OF HISTORY 2(5): 26-27, May 2021

DOI: https://doi.org/10.37547/history-crjh-02-05-08

ISSN 2767-472X

(C)2021 Master Journals

Crossref dol 81 Google

Accepted 22 ${ }^{\text {th }}$ May, 2021 \& Published 29th May, 2021

view that places of power are a man's undertaking Kara Giannopoulos, 1994: 161. The solitary association with power is that her part as a mother is called upon to guard the privileges of the minor replacement as an individual from the show. Notwithstanding, there are commonly that the political activities of magnificent ladies are the consequence of their own yearnings with positive or bad introductions.

\section{Conclusion}

Finally, the courtesan at Byzantium didn't appreciate a similar appreciation as they had in days of yore, and consequently the utilization of the word from the sources is by all accounts powerless. Most of them had broad instruction, they were especially delightful, refined and managed their own property. From the poor whores who furrow the roads to discover a client, to the special whores who are continually evolving supporters, it is difficult to discuss stagnation. Their principle include was the appropriation of splendid shadings, solid scents and serious prepping, which filled in as a methods for drawing in clients. In fact, this extravagant dress and hot preparing was not just piece of the expert appearance of public men, it additionally filled in as an unmistakable contrast from the legitimate. With the progression of time, the misfortune looked by ladies during the time spent advancement is escalating as they face mature age and actual decay. The most fortunate ones figured out how to make a legitimate marriage or live as a couple with a mate.
Byzance, Travaux etMemoirs, Monographies 3, Paris.

2. MacMillan 1997. The Complicatedthousand years, Pisciotta, Alexander W. as byzantinische Jahrtausend, Miinchen.

3. Cavallo, G. 2000. men.In:A. M. Talbot, men and strict life in Byzantium.HampshireVerint.

4. Rothman, David 1996. men in late relic. London, 1992.Trans.Stathis Komninos, Women in late antiquity.Athens.

5. Scull, Andrew. 2003. men of Byzantium.London.

6. Simon, Jonathan 1993. A hypothesis of semiotics. Bloomington, 1977. Trans. Efi Kallifatidi, Semitic theory. Alonc.

\section{REFRENCES}

1. Melossi, Dario.1991. Le statut de la femme a 